\title{
CATEGORIES OF INCOME DISTRIBUTION IN PRIMARY COMMODITIES EXPORTED BY DEVELOPING COUNTRI- ES: SOME CONCEPTUAL AND METHODOLOGICAL PROBLEMS
}

\author{
Korkut BORATAV
}

\section{THE FRAMEWORK}

The problem of primary commodities, as related with international trade, was, at times, the major issue which predominated international forea on the so-called "New International Economic Order" (NIEO) in the second half of the 1970s. As the NIEO controversy developed away from a confrontational route into a time -consuming bargaining process, certain potentially explosive demands of the Third World on commodities receded into the background, and the whole set of problems was reduced into the ways and means of securing price stability for a number of commodities, with a Common Fund as the institutional framework to realise this objective.

The year 1979 witnessed the agreement on the essential features of the Common Fund. The compromise formula on the Fund reached in. Geneva in 1979 is far from what was originally envisaged when the idea was launched four years ago. But, whatever the deficiencies of the Common. Fund as it is emerging now, the problem of price stability ought to be considered a crossedout item in the agenda of the "North-South Dialogue", and other, and more fundamental problems of trade on primary commodities are likely to be drawn into the bargaining process.

One of these explosive problems is the more-or-less forgotten demand of the Third World countries on "increasing the participation of developing countries in the transport, marketing and distribution of their exports [of primary commodities] and their share in the earnings therefrom."

1 Manila Declaration and Programme of Action of the Group of 77, Part Two, Section One, Paragraph $4 \mathrm{~h}$. 
which aim to "increase the share of the earnings of developing countries" from commodities exported by them should be based on an analysis of the "share of developing countries in the final consumer price." 2 In other words, taking the final price of primary commodities in the terminal markets as the starting point, categories of income distribution ought to be defined and measured as a precondition of arriving at a clear understanding the problem at hand.

It is significant that UNCTAD started working on these lines in the course of the preparations for the 1976 Nairobi Conference. ${ }^{3}$ Since the Nairobi Conference pushed all the commodity issues to the background except, naturally, price stability problems, and hence the Common. Fund; a slowing-down of the studies concerning market structures was witnessed after $1976^{4}$ But in the coming years, with the apparent elimination of the price stability issue, problems of improving the market structure of primary commodities with a view to increasing the share of the developing countries in the final price are likely to come to the fore. ${ }^{5}$ If this proves to be the case, we are likely to witness an

2 UNCTAD, "Action on Commodities, Including Decisions on an Integrated Programme in the Light of the Need for Change in the World Commodity Economy" (TD/184), Paragraph 69.

3 "Rapport existant entre les prix à l'exportation et les prix à la consommation de certains produits de base exportés par les pays en développement" (TD/ 184 / Supp. 3); "Relations entre les prix du minerai de fer et ceux de l'acier" (TD / B / C.1 / 142); "Marketing and Distribution System for Cocoa" (TD/ B / C. 1/164); "Marketing and Distribution Systems for Hides, Skins, Leather and Leather Footwear" (TD/B/C. 1/ 163).

4 "The World Market for Manganese: Characteristics and Trends" (TD / B / IPO / MANGANESE / 2); "The World Market for Phosphates: Characteristics and Trends" (TD / B / IPC/ PHOSPHATES / 2); and, "Marketing and Distribution of Tobacco" (TD/ B / C.1/205). References to these studies in this paper in the following paragraphs will use their UNCTAD symbols only.

5 There remain only two other areas of controversy: First, indexation, which is more suitable for cartel-type action, and, hence, outside the effective agenda of North-South Dialogue.Second,the establishment of a complementary financial facility for compensating commodity-specific export shortfalls of developing countries; an issue which does not raise major problems of structural reform, but which is, nevertheless, the subject matter of a heated controversy on competence etc. between IMF and UNCTAD. 
increase in the number of studies on market structure of commodities aiming at analysing processes of income distribution at the international level.

The purpose of the present paper is to outline a conceptual and methodological framework in measuring categories of distribution for primary commodities exported mainly by developing countries. Elements of such an analysis exist in the abovementioned UNCTAD studies in which attempts were made to measure the differential between the prices paid by consumers in developed countries and prices received by (unit export values of) developing countries. ${ }^{6}$ This paper intends to carry forward the methodology used in these studies, and make a number of corrections thereto, mainly in the following lines:

a) In measuring price margins, to start, not with the unit export value, but with the price received by producers; and to analyse the elements which account for the difference between unit export value and price received by producers.

b) To deduct unit production costs of the commodity in developing countries from the final price. In calculating production costs, material costs of production only, i.e. seeds, fertilizers, insecticide, fuels, amortization of capital equipment etc. are to be taken into consideration. Wages, interest and rent, as far as they are actual, paid-in elements are treated not as production costs, but as categories of net output; whereas implicit factor payments are altogether excluded.

c) To deduct supplementary elements of value added, and specific costs therein, from the final price of the commodity, which necessitates:

i. Deduction of the necessary costs of transportation, handling and storage, both at national and international levels; and,

ii. Deduction of all elements of value-added (and specifie costs therein) in those commodities where further processes of transformation and production takes place before the commodity reaches the consumer.

After these deductions and corrections, the final price of the commodity represents the net output created by the producers of the commodity in the developing country. An analysis of dist-

6 See in particular TD / 184/ Supp. 3, passim;TD/ B/ C. / 205, pp. 72-78; $\mathrm{TD} / \mathrm{B} / \mathrm{C} .1 / 164$, pp. 22-34. 
ribution is significant only if it establishes the shares received by various economic and social categories within the net output of any product. In the case of commodities exported by developing countries, the relevant categories are:

(a) The share of the "producers" of the developing country (to be denoted by V). It is not attempted to measure the categories of distribution which share between themselves the part of the net output seemingly appropriated by the "producers". Although the analysis would remain incomplete without the inclusion of these elements, empirical difficulties seem to be surmountable at this stage. For illustrative purposes, the following elements of distribution which actually make up the "share of producers"in our analysis can be cited:

i. Net income of farmers (in the case of agricultural commodities produced under conditions of family farms or "petty commodity production")

ii. Profits net of interest and commercial margins (in the case of minerals or agricultural commodities produced under capitalist conditions or under state ownership)

iii. Rents actually paid by farmers to landlords

iv. Wages of agricultural or mine workers

$v$. Interest paid by agricultural and mining enterprises and farmers to the private moneylenders or to the banking systım.

b) Commercial profits within the exporting country $\left(\mathrm{R}_{\mathrm{x}}\right)$. If data is available, (which does not seem very likely) an attempt should be made to differentiate between:

i. Commercial profits (or losses) accruing to state trading or ganisations of developing countries (phosphates, cocoa etc.)

ii. Commercial profits accruing to private and local traders and exporters;

iii. Commercial profits accruing to foreign (and multinational) firms in the case when these firms purchase directly from producers or when they have investments in the productive secter itself.

c) Taxes and similar charges on the commodity collected by the government of the exporting country $\left(\mathrm{T}_{\mathrm{x}}\right)$. 
The f.o.b. unit export value, minus unit production costs, and minus the necessary unit transport and storage costs between the production and export centers, is equal to the sum of $(\mathrm{V})$, $\left(R_{x}\right)$ and $\left(T_{x}\right)$ cited above respectively in sub-paragraphs (a), (b), and (c).

d) Commercial profits within the developed country $\left(\mathrm{R}_{\mathrm{m}}\right)$. Since industrial profits, together with the other elements of value added in case of further stages of production and processing are to be deducted from the final price, this item can be considered to represent the pure "commercial margin" of the distributive network as a whole including wholesale and retail profits, as well as profits emanating from international trade in commodities. Speculative gains, in cases where futures markets and exchanges exist, are similarly to be included in this category.

e) Taves and similar charges on the imported commodity collected by the government of the developed country $\left(\mathrm{T}_{\mathrm{m}}\right)$.

Thus, the final price of a commodity in a developed country $\left(\mathrm{P}_{\mathrm{f}}\right)$, consists of unit material costs of production in the exporting country (C), plus, storage, handling, and national and international transportaion (F), plus, value-added in further stages of production (and specific costs thercin), processing and transformation in importing countries $\left(\mathrm{Y}_{\mathrm{mi}}\right)$, and,, lus, net output created by producers in the developing country $\left(\mathrm{Y}_{\mathrm{x}}\right)$. To 1estate:

$$
\begin{aligned}
& P_{\mathrm{f}}=\mathrm{C}+\mathrm{F}+\mathrm{Y}_{\mathrm{m}}+\mathrm{Y}_{\mathrm{x}} \\
& \mathrm{Y}_{\mathrm{x}}=\mathrm{P}_{\mathrm{f}}-\mathrm{C}-\mathrm{F}-\mathrm{Y}_{\mathrm{m}}
\end{aligned}
$$

Net output consists of the five major elements referredto above, namely:

$Y_{x}=V+R_{x}+T_{x}+R_{m}+T_{m}$ (iii). which provides us the basic categories of distribution relevant on commodities in international trade.

Two composite and basic ratios of distribution can be obtained from relation (iii):

a) Degree of exploitation of commodity-exporting country:

$$
\mathrm{S}_{1}=\left(\mathrm{R}_{\mathrm{m}}+\mathrm{T}_{\mathrm{m}}\right) /\left(\mathrm{V}+\mathrm{R}_{\mathrm{x}}+\mathrm{T}_{\mathrm{x}}\right)
$$


b) Degree of exploitation of commodity producers ${ }^{7}$ :

$$
\mathrm{S}_{2}=\left(\mathrm{R}_{\mathrm{m}}+\mathrm{T}_{\mathrm{m}}+\mathrm{R}_{\mathrm{x}}+\mathrm{T}_{\mathrm{v}}\right) /(\mathrm{V})
$$

With the necessary methodological corrections it seems conceivable that available data on some commodities can, to some degree, be utilised to establish the kasic relation (iii) formulated in the previous paragraph. Without corrections and adjustments in these lines, inter-commodity comparisons using the share of unit export value in the final price of a commodity as an indicator of distribution at the international level, as undertaken in previous UNCTAD work (e.g. TD/184/Supp. 3), cannot be considered very significant. Thus, the fact that the share of unit export value of iron ore in the wholesale price of steel is $7 \%$ in U.S.A. in 1973, whereas the corresponding ratio for cocoa powder is $40 \%$ (Ibid., Tables 1 and 7) does not convey much information as far as relations of distribution are concerned. The difference between the two percentages may conceivably be explained by the mere fact that steel production. subjects iron ore into a complex process of further transformation with the use of a number of additional raw materials, energy, and sophisticated capital equipment and technology: whereas this is not true for cocoa powder.

The elements of the basic relation (iii) above, are components of the final price in its corrected form, either in absolute values, or preferably, as shares, where we take $Y_{x}=100$. It is a simple step forward to multiply al! the elements used in building up equation. (iii) with the physical quantities of the commodity in its final form, and, thus, to arrive at total value of net output and its components. In some cases, data are more suitable to determine directly total values, instead of unit values (or prices). Both types of procedure are equally valid, and, in the final analysis, lead to the same result.

7 (V), as defined above, may actually include a number of "surplus" elements. Profits, rents and interest which are, of necessity inciuded under "producers' income" are such surplus elements. Therefore, the "real" degree of exploitation can be defined by including items (ii) and (iv) in the dividend of the ratio defined in relation (v) above. This approach interpretes "producers' income" as the sum of wages and net income of farmers only. But, it seems empirically impossible to make this correction at the present stage. 
There are a number of theoretical and conceptual questions in using the above-mentioned methodology, and in interpreting the results obtained from an empirical application of equations (iii), (iv) and (v). Some of these questions which we shall pose now, will be briefly dealt with in the final section of this paper:

(a) Are we justified to extend the application of the proposed methodolcgy into products where the process of transforming the raw material involved takes a complex form, where further production takes place with the use of additional commodities as inputs and under capital-and technology-intensive processes?

b) How far are we justified to use relations (iv) and (v) above as "exploitation ratios", particularly in cases of products with very low price elasticities of demand, monopolistic pricing practices and hign excise taxes, since the high price of the relevant p oduct in these cas's might include value created in, and transformed from, other sectors of the developed economy?

c) How far are we justified to see this problem as a commodity-specific problem in which exporters are developing countries? Should not the commodity-specific analysis be complemented by a symmetrical analysis in which differentials between the final prices of imported manufactured goods in developing countries and production and export prices in developed countries are to be measured and translated into a similar scheme of distribution as that proposed for primary commodities in this paper?

\section{ILLUSTRATIONS}

\section{A. Introductory Remarks}

An attempt will be made in the following paragraphs to provide two illustrations on the empirical application of the framework outlined above. Bananas are taken as representing a commodity which does not undergo any significant process of transformation after it is imported, whereas tobacco is considered as a typical commodity which is subjected to further stages of processing and transformation in the importing country. 
Data provided by previous UNCTAD work on the two commodities will be used in the illustrations below. For bananas, Table 10 a of TD / 184/Supp. 3; reproduced as Table A in this paper, will provide the basic information, and for tobacco-cigarettes Table 22 in TD/B / C.1/205. reproduced as Table B below will be used. Since the data in these tables are not presented in conformity with the requirements of the ccnceptual framework outlined in the previous section, a number of arbitrary, but intuitive and common-sense corrections and manipulations are freely made with the figures therein, particularly with the tobaccocigarettes data, which, in the form they are presented in Table B, are of little use for our purposes. Therefore, the final results should, in no case, be interpreted as reflecting the actual relations of distribution, but, rather, as examples merely aiming to demonstrate that calculations on the lines of the proposed methodology are feasible.

\section{B. Commodity Which Does not Undergo a Significant Process of Transformation in the Importing Country: Bananas}

For bananas, a reconstructed and "corrected" version of Table A is presented as Table I below. Average retail price for bananas is given as 327 dollars per tonne in the former Table, which is reproduced in Line $12 \mathrm{cf}$ Table I. (All the following figures in this sub-section are to be understood as dollars.) Using the notation of Par. 3 above, $P_{f}=327$.

Unit costs of production in the original Table A seem to include implicit factor payments which leave practically no margin for producers, whereas the concept of production costs outlined above excludes implicit factor payments and covers only the material costs of production. $20 \%$ of the gross revenue of producers (Lines 1-3 of Table A) is assumed to be equal to unir production costs in this sense. Hence, $\mathrm{C}=0.2 \times 38=8$ (Rounded). (Line la of Table I).

Necessary unit costs of transportation and storage (F), can be divided into (a) those in the exporting country (Lines $4+5+6$ in Table A, Line 2 in Table I), (b) difference between c.i.f. and f.o.b. prices (Line 10 in Table A, Line 6 in Table I), and, (c) those in the importing country (Lines $11+14$ in Table A, Line 8 in 
TABLE A- BASIC INFORMATION ON PRINCIPAL ELEMENTS OF PRICE AND COST IN THE WORLD BANANA ECONOMY, 1971.

\begin{tabular}{|c|c|}
\hline Cost and Revenue Item & $\begin{array}{r}\text { Unit Value per Tonne } \\
\text { (Dollars) }\end{array}$ \\
\hline 1. Production costs & 34 \\
2. Transport up to wholesaler & 3 \\
3. Gross margin of producer & 1 \\
1- 3ross receipt of planters at delivery to whole- & 38 \\
salers & 24 \\
4. Packing and storing & 4 \\
5. Transport up to port & 5 \\
6. Handling and loading & 2 \\
7. Export duties & 6 \\
8. Other taxes & 6 \\
9. Gross margin and overhead costs of exporters & 85 \\
1-10. F.o.b. price & 38 \\
\hline 10. Freight and insurance & 123 \\
1-10. C.i.f. price & 16 \\
\hline 11. Unloading and handling at port of arrival & 23 \\
12. Import duties & $-0,3$ \\
13. Gross margin or commission of importers & 161 \\
1-13. Importers'sale price & 62 \\
\hline 14. Gross margin of storing houses & 223 \\
\hline 1-14. Sale price at storing house & 104 \\
\hline 15. Gross margin of retailers & 327 \\
1-15. Retail price & \\
\hline
\end{tabular}

Source: Reproduced from "Rapport existant entre les prix à l'exportation et les prix à la consommation de certains produits de base exportés par les pays en développement", op. cit, Table 10 a.

TABLE I- ELEMENTS OF PRICE AND COST IN THE PRODUCTION AND MARKETING OF BANANAS (Based on Table A)

\begin{tabular}{|c|c|} 
& $\begin{array}{c}\text { Unit Values per } \\
\text { Tonne in Dollars }\end{array}$ \\
\hline 1. Gross revenue of banana producers of which, & 38 \\
a)Material costs of production & $(8)$ \\
b) Net revenue of producerss & $(30)$ \\
2. Transportation, packing and storage in exporting & 33 \\
country & 8 \\
3. Taxes and similar charges in exporting country & \\
of which, & $(2)$ \\
a) Export duties & $(6)$ \\
b) Other taxes & 6 \\
4. Gross margin of exporters & 85 \\
5. F.o.b. price (1+2+3+4) & 38 \\
6. Freight and insurance & 123 \\
7. C.i.f. price (5+6) & 78 \\
8. Unloading, storage and transport in importing co- \\
untry & 23 \\
9. Import duties & 33 \\
10. Excise taxes & 71 \\
11. Commerical profits of importers and of the distribu- & 327 \\
tive network & \\
12. Retail price & \\
\hline
\end{tabular}


Table 1), which give the sum of $F=149$. This sum seems to be an over-estimation of the "necessary" costs of transportation etc., particularly since the structure of ownership and organisation of international shipping inevitably gives rise to elements of surplus, over and above the necessary costs, appropriated mostly by developed countries which is implicit in the c.i.f. - f.o.b. price differential. But no correction is made for this factor.

Since no further element of value-added is assumed to be existing for bananas, net output created by banana producers is equal to:

$$
\begin{aligned}
& \mathrm{Y}_{\mathrm{x}}=\mathrm{P}_{\mathrm{f}}-\mathrm{C}-\mathrm{F} \quad \text { (ii) } \\
& \mathrm{Y}_{\mathrm{x}}=327--8-149=170
\end{aligned}
$$

As for the distributive shares in net output, "producers' income" is equal to:

$$
\mathrm{V}=38-8=30,
$$

according to the assumption made above. (Line Ib of Table I)

Commercial profits in the exporting country are taken to be represented by Line 9 of Table A, (Line 4, Table I) which includes exporters' costs, a fact which might compensate for the disregard of profit elements of a commercial nature in Lines 4,5,6, of Table A (Line 2, Table I). Therefore:

$$
\mathrm{R}_{\mathrm{x}}=6
$$

Taxes on bananas by the government of the exporting country are included in Line $7+8$ of Table $\mathrm{A}$ and in Line 3 of Table I:

$$
\mathrm{T}_{\mathrm{x}}=2+6=8
$$

Excise taxes on bananas in the importing country are included in the retail price, but there is no estimate of their size. We assume excise taxes to be $10 \%$ of retail price, which gives a margin of 33 (Line 10 of Table I). This figure, plus import duties provide the sum of total taxes in the final price:

$$
\mathrm{T}_{\mathrm{n} 1}=33+23=55 \text { (Rounded) }
$$

Commercial profits in the importing country are equal to Line 15 of Table A, minus excise taxes as estimated above, plus Line 13 in Table A, which gives an approximate value of:

$\mathrm{R}_{\mathrm{m}}=71$ 
Our basic relation (iii) can be restated:

$Y_{x}=V+R_{x}+T_{x}+R_{m}+T_{m}$ (iii). For bananas, the corresponding values are:

$170\left(\mathrm{Y}_{\mathrm{x}}\right)=30(\mathrm{~V})+6\left(\mathrm{R}_{\mathrm{v}}\right)+8\left(\mathrm{~T}_{\mathrm{x}}\right)+71\left(\mathrm{R}_{\mathrm{m}}\right)+55\left(\mathrm{~T}_{\mathrm{m}}\right)$ In percentages:

$100\left(\mathrm{Y}_{\mathrm{x}}\right)=17.7(\mathrm{~V})+3.5\left(\mathrm{R}_{\mathrm{x}}\right)+4.7\left(\mathrm{~T}_{\mathrm{x}}\right)+41.8$

$\left(\mathrm{R}_{\mathrm{ra}}\right)+32.3\left(\mathrm{~T}_{\mathrm{m}}\right)$

Degree of exploitation of banana exporting country:

$$
\mathrm{S}_{1}=(71+55) /(30+6+8)=126 / 44=2.86
$$

Degree of exploitation of banana producers:

$$
\mathrm{S}_{2}=(71+55+6+8) /(30)=(140) /(30)=4.67
$$

\section{Commodity Which Undergoes a Significant Process of Trans- formation: Tobacco-Cigarettes}

In a commodity like bananas in which no significant process of transformation in the importing country is assumed to take place, the sum total of the surplus which is realized in the circulation process (commercial profits and excise taxes) can safely be considered to be originating in the production of the relevant commodity. But in a commodity like tobacco which undergoes a significant degree of industrial transformation (into cigarettes), the sum total of the surplus realized in the marketing of the final product ought to be attributed both to the tobacco and cigarette production stages. This brings a new element into the forms of calculating the distributive shares which was outlined in the previous paragraphs for bananas.

In the case of a final product in which a primary commodity mainly exported by developing countries occupies a dominan ${ }^{+}$ place both in physical and economic terms, one can put forward the premise that the surplus realised in the circulation process originates mainly in the production of the commodity, i. e. in the developing country. The problems of defining the border-line between products where surplus is mainly created by commodity producers, and those where surplus is mainly created by industrial producers are discussed in the final section of this paper.

In the former case, which is assumed to be relevant for tobacco-cigarettes, the following method of allocating the surplus 
between cigarette production and tobacco production is proposed; :

a) The material and direct costs of cigarette manufacturing is computed. This includes:

i. Import costs of leaf and processed tobacco $\left(c_{1}\right)$

ii. Containers, cellophane, electricity, fuel, depreciation or amortization of capital equipment and other material costs $\left(c_{2}\right)$

iii. Wage costs of tobacco processing and cigarette manufacturing in importing country $(\mathrm{w})$

b) Costs internal to the firm, but which should be cosnsidered part of the surplus, such as interest and rent payments and market promotion (advertising) costs, are excluded. These surplus elements are subsequently considered to be part of commercial profits.

c) The average rate of mark-up for manufacturing in the importing country (r) is multiplied with the material and direct costs as defined above:

$\mathrm{s}_{\mathrm{cig}}=\mathrm{r}\left(\mathrm{c}_{1}+\mathrm{c}_{2}+\mathrm{w}\right)$ (vi), which gives us the surplus imputable to cigarette production.

d) Material production costs which are specific for cigarette manufacturing $\left(\mathrm{c}_{2}\right)$ plus wages in cigarette manufacturing $(\mathrm{w})$ and plus the surplus imputable to cigarette production $\left(\mathrm{s}_{\mathrm{cig}}\right)$ are deducted from the final price of cigarettes (or from gross output as defined by the value of sales). The sum, $c_{2}+w+s_{\text {cig }}$ is equal to $Y_{m}$ as defined in equation (ii) above.

In defining an average rate of mark-up to be applied to total direct costs in cigarette manufacturing, it is preferable to take the average of typical industries of consumption goods in which imported commodities de not predominate. This procedure implies that an actual rate of profit in a commodity-dominated industry which exceeds the average profit rate in the typical industries (all profit rates defined as rates of mark-up on direct costs), is due to the exploitation of commodity producers via the circulation process, and which is realized as (or should be considered part of) commercial profits. 
An alternative procedure of allocating the surplus between cigarette and tobacco producers would be to use a standard profit / wage coefficient for the "typical" industry and to multiply the wage costs of the cigarette industry with this coefficient. This procedure of substituting an average wage/profit coefficient for the average rate of mark-up (or profit rate) would make things easier in some respects, particularly since wage bills are easily definable in almost all industries. Nevertheless, an average rate of mark-up on direct costs seems to be a more widely used behavioural parameter than an average profit/ wage coefficient.

A final problem to be resolved is the treatment of excise taxes on cigarettes. Since tax proceeds are also part of the surplus, one should similarly allocate them between tcbacco and cigarette production. The method to be used will be illustrated in the calculations made in the following paragraphs. It should also be pointed out that the figures of Table B to be used in the calculations are based on "total retail value", and other total values which are components of the retail value; whereas those used in bananas represented unit values. But this difference dces not effect our methodology as outlined above; since the two procedures are directly connected. ${ }^{8}$

Table B will be used solely for illustrative purposes, since it refers to U.S.A., a developed country which is also a major tobacco producer. It will be presumed in our calculations that the figures in that table pertain to a hypethetical tobacco importing developed country, and "payments to tobacco growers" in the same table represent gross revenue of tobacco producers in the exporting country; "total payments for leaf and processed tobacco" represent f.o.b. export value of the producing country. It will also be presumed that total retail value excludes the "necessary transportation and storage costs" at the national and international levels. A number of arbitrary manipulations will

8 In the case of a significant process of transformation, and when calculations are made in unit values of final product, one should make the necessary corrections by considering the transformation coefficients of primary commodities into final products; e.g. $1 \mathrm{~kg}$. of cigarettes $=1.5 \mathrm{~kg}$. of leaf tobacco. But no correction is necessary in our case, since payments to tobacco growers are given in total value terms. 
also be made to fill in the missing information necessary for the type of calculation outlined above ${ }^{9}$ With these modifications, Table B is transformed into Tablo II below.

There are four additional operations necessary to arrive at the distribution categories of equation (iii) (All the figures in the fellowing paras aphs in this section are to be understood as million dollars).

a) First, to calculate the surplus imputable to cigarette manufacturing as put forward above. Using a $15 \%$ rate of mark-up $(\mathrm{r}=0.15)$ and considering that line 4 in Table $\mathrm{I}=\mathrm{c}_{1}=$ 1145 ; and, Line $5=\mathrm{c}_{1}=778$; and, Line $6=\mathrm{w}=345$ :

$\mathrm{s}_{\mathrm{cig}}=\left(\mathrm{c}_{1}+\mathrm{c}_{2}+\mathrm{w}\right)$

$\mathrm{s}_{\mathrm{cig}}=0.15(1145+6778+345)=340$ above ${ }^{10}$ :

b) Second, to compute $Y_{m}$ of equation (iii) as explained

$$
\mathrm{Y}_{\mathrm{m}}=\mathrm{c}_{2}+\mathrm{w}+\mathrm{s}_{\mathrm{cig}}=1463
$$

c) Third, to allocate excise taxes between tobacco growing and cigarette manufacturing "sectors". To do this, total retail value is divided into three basic elements reproduced in Table III below. The share of excise taxes on the sum of gtoss output in the two sectors, i. e. Line (1) of Table III, divided by the sum of Lines (2) and (3), equals 0.7 ; and thus, total excise taxes are allocated to the two sectors in this proportion:

Excise taxes imputable to cigarette production $=0.7 \times$ $1463=1025$

Excise taxes imputable to tobacco production $=0.7 \times$ $5456=3821$

$920 \%$ of gross revenue of tobacco producers is assumed to make up the material production costs of tobacco; $20 \%$ of an ill-defined "other" item within the category of "value added in tobacco manufacturing" (Line 8c in Table B) is considered to represent depreciation and thus included in "material production costs of cigarettes"; the margin between f.o.b. export value and producers' gross revenue is assumed to be equally shared between $T_{x}$ and $R_{x}$.

10 It should be made clear that $Y_{m}$ is gross output imputable to cigarette manufacturing, excluding tobacco inputs. This concept of gross output is divided into its value added elements, namely wages and surplus; and material costs of production excluding tobacco inputs. 
TABLE B- BASIC INFORMATION ON UNITED STATES CIGARETTE INDUSTRY, 1972

\begin{tabular}{|c|c|}
\hline Cost Item & $\begin{array}{c}\text { Retail Value } \\
\text { (Million dolars) }\end{array}$ \\
1. Value of production (ex-factory) & $\mathbf{4 2 1 2}$ \\
2.Primary and intermediate inputs & $(49)$ \\
3. Unstemmed leaf tobacco $\quad$ Processed tobacco, of which, & $(1096)$ \\
4. Payments to tobacco growers & {$[625]$} \\
b. Other & {$[471]$} \\
5. Containers, cellophane etc. & $(398)$ \\
6. Fuel and electric energy & $(11)$ \\
7. Cost of services, of which, & $(470)$ \\
a.Advertising & {$[280]$} \\
b. Other & {$[190]$} \\
8. Value added, of which, & $(2188)$ \\
a.Salaries & {$[58]$} \\
b. Wages & {$[287]$} \\
c. Other (depreciation, property-type income, & {$[1843]$} \\
indirect business taxes) & $\mathbf{2 7 0 7}$ \\
9.Trade margins & $\mathbf{2 1 5 1}$ \\
10. Federal taxes & $\mathbf{2 6 5 9}$ \\
11.State taxes & $\mathbf{1 1 7 6 5}$ \\
12.Total retail value & \\
\hline
\end{tabular}

Source: Reproduced from "Marketing and Distribution of Tobacco",/ op. cit., Table 22

Note: Figures in square brackets are components of the figures immediately above.

TABLE II- COST AND REVENUE ITEMS IN TOBACCO AND CIGARETTE PRODUCTION (Based on Table B)

\begin{tabular}{|c|c|}
\hline & $\begin{array}{l}\text { Total Value in } \\
\text { Million Dollars }\end{array}$ \\
\hline $\begin{array}{l}\text { 1. Gross revenue of tobacco producers of which } \\
\text { a) Material costs of production } \\
\text { b) Net revenue of producers } \\
2 \text { Taxes from exports } \\
3 \text { Traders' abnd exporters' margin } \\
4 \text { F.o.b. export value }(1+2+3) \\
5 \text { Material costs of cigarette manufacture excluding to- } \\
\text { bacco inputs of which } \\
\text { a) Containers, cellophane etc. } \\
\text { b) Fuel and electricity } \\
\text { c) Depreciation } \\
\text { 6. Wages and salaries in cigarette manufacture } \\
\text { 7. "Other" elements in value added } \\
\text { (Rent, interest and undefined) } \\
\text { 8. Payments for services out of surplus } \\
\text { (Advertisement etc). } \\
\text { 9. Trade margins } \\
\text { 10. Excise taxes } \\
\text { 11. Total retail value }(4+5+6+7+8+9)\end{array}$ & $\begin{array}{r}674 \\
(135) \\
(539) \\
235 \\
236 \\
1145 \\
\\
778 \\
(398) \\
(11) \\
(369) \\
345 \\
\\
1474 \\
470 \\
2707 \\
4846 \\
11765\end{array}$ \\
\hline
\end{tabular}


TABLE III - BASIC ELEMENTS OF TOTAL RETAIL VALUE

\begin{tabular}{|l|c|}
\hline & $\begin{array}{c}\text { Total Value in } \\
\text { Million Dolars }\end{array}$ \\
\hline 1. Total taxes & 4846 \\
2. Contribution of cigarette production net of excise taxes & 1463 \\
( $\left.\mathrm{Y}_{\mathrm{m}}\right)$ & 5456 \\
3. Contribution of tobacco production net of excise taxes & 11765 \\
4. Total
\end{tabular}

It is now possible to establish the categories of distributive shares as defined in equations (ii) and (iii) above ${ }^{11}$.

$\mathrm{Y}_{\mathrm{x}}=\mathrm{P}_{\mathrm{f}}-\mathrm{C}-\mathrm{Y}_{\mathrm{m}}$ (ii). and since,

$\mathrm{C}=$ Line la of Table II $=135$.

$\mathrm{Y}_{\mathrm{m}}=2488$

$\mathrm{Y}_{\mathrm{x}}=11765-135-2488=9142$, which is the net output imputable to tobacco producers, the distributive shares of which we are trying to establish.

$Y_{x}=V+R_{x}+T_{x}+R_{m}+T_{m}$ (iii), and since,

$\mathrm{V}=$ Line $1 \mathrm{~b}=539$

$\mathrm{R}_{\mathrm{x}}=$ Line $3=236$

$\mathrm{T}_{\mathrm{x}}=$ Line $2=235$

$\mathrm{R}_{\mathrm{m}}=$ Line $7+$ Line $8+$ Line $9-\mathrm{s}_{\mathrm{cig}}=1474+470+$ $2707-340=4311 ;$ or,

$\mathrm{R}_{\mathrm{m}}=\mathrm{Y}_{\mathrm{x}}-\left(\mathrm{V}+\mathrm{R}_{\mathrm{x}}+\mathrm{T}_{\mathrm{x}}\right)-\mathrm{Tm}=9142-(539+$ $236+235)-3821=4311$

$\mathrm{T}_{\mathrm{nn}}=$ Tax imputable to tobacco as calculated above $=3821$, which gives:

$9142\left(\mathrm{Y}_{\mathrm{x}}\right)=539(\mathrm{~V})+236\left(\mathrm{R}_{\mathrm{x}}\right)+235\left(\mathrm{~T}_{\mathrm{x}}\right)+4311\left(\mathrm{R}_{\mathrm{m}}\right)$ $+3821\left(\mathrm{~T}_{\mathrm{m}}\right)$

In percentages:

$100\left(\mathrm{Y}_{\mathrm{x}}\right)=5.9(\mathrm{~V})+2.6\left(\mathrm{R}_{\mathrm{x}}\right)+2.6\left(\mathrm{~T}_{\mathrm{x}}\right)+47.1\left(\mathrm{R}_{\mathrm{m}}\right)$ $+41.8\left(\mathrm{~T}_{\mathrm{m}}\right)$

11 It will be recalled that the notation of equations (i)-(iii) are to be interpreted here, not as unit values; but as total values; and, that, $\mathrm{P}_{\mathbf{x}}$ is defined net of transportation etc. costs, and, hence, no $\mathrm{F}$ exists. 
Degree of exploitation of tobacco growing country:

$$
\mathrm{S}_{1}=(4311+3821) /(539+236+235)=8132 / 1011=8.04
$$

Degree of exploitation of tobacco producers:

$$
\mathrm{S}_{2}=(4311+3821+230+235) /(539)=8603 / 539=15.90
$$

\section{FURTHER QUESTIONS AND CONCLUSIONS}

We now come back to the three questions posed at the end of our first section. These questions will lead us to analyze, a) the case of industrial prodlicts in which a single commodity is no longer predominant; b) the case of monopoly pricing and excessive taxation which may imply a process of surplus transfer from other sectors of the importing country; and, (c) the possibilities to undertake a parallel and symmetrical analysis for industrial goods imported by developing countries and the implications thereof.

\section{A. Industrial Products With a Low Degree of Commodity- Dependence.}

Since all industrial products are manufactured by using raw materials as inputs some of which are imported from developing countries, is it justifiable to use the methodology develoin the previous paragraphs for all of them? This question should be answered in the negative due to the following reasons:

The methodology developed above is based on the implicit theoretical premise that the structural and organisational characteristics of international trade in commodities between developing and developed countries, as well as the relations of production in the commodity sectors lead to a situation in which a process of "exploitation through trade" and a consequent transfer of surplus from developing to developed countries take place. In cases where imported commodities make up an insignificant portion of the final product and where the product is a combination of a number of raw materials and the result of a sophisticated process of industrial transformation and of technological know-how, and a significant mass of value-added is created within industry itself, it would be entirely misleading to impute the major portion of the surplus emanating from such a process of production to a single commodity or even to the basket of imported commodities. Electronics, engineering, petrochemicals, 
and even textiles would be evident cases in point. Many metallurgical industries ought to be excluded too.

In the above-mentioned cases, one could follow a procedure in which industrial processes of primary stage, using the commodity in question in its raw form directly as inputs could be differentiated from higher stages of production and the proposed methodology could presumably be applicable to the primary stage. But, it would be difficult to undertake a significant analysis even at the primary stage of transformation, since imported commodities are, de facto integrated vertically to the overall economic mechanism of the importing country; and it would be totally unrealistic to presume that the commodity-using industry at the first level can appropriate the whole (or the major part of) surplus due to the low price of commodities. In other words, the primary chain in the vertical structure of production cannot both underprice the imported commodity as a buyer, and overprice the intermediate product to its purchaser at the higher level. If the analysis cannot be undertaken at the primary stage of industrial transformation, it would be even more unfruitful to carry it over to the higher stages.

But where to draw the border-line? For practical purposes, a number of quantitative categories can be used to build-up criteria on delineating the border-line between commodity- dependent products and others: (a) F.o.b. export value of the commodity, and, (b) gross revenue of commodity producers in the exporting country, can be compared with, (c) material production costs in the importing country, or with (d) wage bill expended in the various stages of transformation and fur ther production ${ }^{12}$. In comparisons of this sort, the fact that the imported commodity in question is assumed to be underpriced, and, consequently the producers underpaid, should always be kept in mind. Comparison of (b) with (d) as formulated above seems to rest on more solid grounds than the other comparisons; and, if so, any product in which the sum of gross payments to the commodity producers in the exporting country exceeds the wage bill expended in further stages of production in the importing country, would be considered a suitable case for the type of quantitative analysis outlined in this paper.

12 If we take the tobacco-cigarette case as an example, $(a)=1145 ;(b)=$ 674; (c) $=778$ and $(\mathrm{d})=348$; and, thus, $\mathrm{c}<\mathrm{a}$; $\mathrm{d}<\mathrm{b}$; $\mathrm{d}<\mathrm{a}$; but, $\mathrm{b}<\mathrm{c}$. 


\section{B. Monopolistic Pricing And Excessive Taxation}

The case of cigarettes shows that the major of the surplus is appropriated through high excise taxes and monopolistic pricing of the industry. Structural characteristics of the cigarette industry and a low price elasticity of demand for cigarettes are the main factors which lead to such a situation. In such a case, it would be extravagant to claim that the whole mass of surplus (after the necessary corrections due to the contribution of cigarette manufacturing as such) is imputable to commodity (tobacco) producers. Monopolistic pricing and excessive taxation imply a process of surplus transfer from other sectors within the importing country. Theoretical and empirical difficulties would prevent the formulation of a methodology which would distribute the mass of surplus (as corrected above) between tobacco producers and other sectors of the importing economy. In this case, the concepts, "degrees of exploitation of the exporting country or of the commodity producers" would be misleading. ${ }^{13}$ Still, the quantitative margins on which these ratios are built can be utilized to show the theoretical maximum level which can be appropriated by the producers, if they would, miraculously, succeed in controlling and owning the whole marketing and productive chain, as well as collecting the tax proceeds of the importing country. Or, the relevant margins would represent the theoretical maximum level of price increases by the producers and exporters which could, hypothetically, be absorbed by the erosion of commercial profits and taxes in the importing country with no price increase to the consumer. It is evident that these "maximums" are purely theoretical magnitudes, with very little, if any, practical or policy implication at the moment.

\section{C. "Symmetrical" Analysis of Industrial Goods Imported}

\section{By Developing Countries:}

If quantitative analysis of distributive shares and price margins on the lines developed in this paper are used as evidence of "exploitation through trade of the developing countries", it is inevitable that, sooner or later, there will be a backlash of

13 This is a case which clearly shows the conceptual difficulties inherent in a calculation of "exploitation rations" via market prices, and the theoretical superiority of a computation through values in the Marxian sense. 
demands to undertake parallel and symmetrical studies on industrial goods imported by developing countries. Indeed, import substitution policies, based on various tools of protecticnism, high rates of indirect taxation, and the consequent price structure reflecting rents of protection and of scarcity in many developing countries seem to produce situations in which wide margins may exist between import costs and prices which the consumers pay for many products exported by developed countries, situations which create a strong impression of parallelism and symmetry with those in commodity importing developed countries. But, how far, in fact, are the two situations similar? Despite the initial impression of parallelism created by superficial observation, exports of manufactures to developing countries are, as a rule, subject to a process of marketing and distribution which is significantly assymmetrical with the mechanisms in which commodities are exported by developing countries. The whole area of international trade is controlled by firms (including transnational corporations) of developed countries, whether imports of commodities from, or exports of manufactures to developing countries are concerned; a situation which creates objective conditions for a one-way traffic in the international transfer of surplus. Moreover, industry in many developing countries are under the direct ownership or indirect (technological etc.) control of firms of developed countries, including TNCs, with the consequent flows of surplus towards the metropoles (via profit remittances, transfer pricing etc.) whereas a parallel and symmetrical situation does not exist in commodity importing developed countries.

These observations lead ús to conclude that studies on price and cost structures and on distributive shares on industrial goods imported by developing countries ought to be a promising futute area of work, but it should be understood and clearly stated at this stage that an identical or parallel methodology for commcdities and for industrial goods would be out of question. The present world economy, in which relations of dependency are continuously reproduced, clearly presents a picture of assymmetry between its metropoles and peripheral areas in the field of international trade, whether it concerns exports of commodities or imports of manufactures by the developing countries. 